\title{
Palatability and chemical anti-predatory defenses in common ascidians from the Antarctic Peninsula
}

\author{
Gil Koplovitz ${ }^{1, *}$, James B. McClintock ${ }^{1}$, Charles D. Amsler ${ }^{1}$, Bill J. Baker ${ }^{2}$ \\ ${ }^{1}$ Department of Biology, University of Alabama at Birmingham, Birmingham, Alabama 35294, USA \\ ${ }^{2}$ Department of Chemistry, University of South Florida, Tampa, Florida 33620, USA
}

\begin{abstract}
Palatability of outer tissues of a suite (12 species) of Antarctic ascidians was evaluated using omnivorous fish and sea star predators. Tissues of $100 \%$ of those tested were unpalatable to fish, while $58 \%$ were unpalatable to sea stars. Lipophilic and hydrophilic extracts of 11 species were incorporated into pellets and tested in fish and sea star bioassays. Only the lipophilic extract from Distaplia colligans caused fish feeding deterrence. Organic extracts from 10 ascidian species were also examined in food pellet assays using an omnivorous amphipod. Only the lipophilic extract of D. cylindrica was a deterrent. Five of the ascidians possessed acidified outer tunics $(\mathrm{pH}<3)$. We tested the ability of acidified krill pellets ( $\mathrm{pH} 2$ to 7 ) to deter fish and sea star predators and found that, while fish readily ingested acidified food pellets $(\mathrm{pH} 2)$, sea stars were deterred at $\mathrm{pH} 5$ or less. Thus either organic or inorganic chemical defenses explain defense in 5 of the 7 ascidian species found unpalatable to sea stars. In contrast, chemical defenses only explain 1 of 12 species found unpalatable to fish, and only 1 of 10 ascidians tested against an amphipod predator. This predator-specific pattern of chemical defense may reflect greater predation pressure on ascidians from Antarctic sea stars. Alternatively, Antarctic ascidians may rely on other factors such as the toughness of their tunic or sequestration of heavy metals such as vanadium to inhibit feeding by Antarctic fish, a taxonomic group known to lack strong jaws.
\end{abstract}

KEY WORDS: Ascidian · Antarctica - Palatability - Chemical defense - Benthic ecology Resale or republication not permitted without written consent of the publisher

\section{INTRODUCTION}

Ascidians as a group represent an important component of benthic marine communities (Tatian et al. 1998, Monteiro et al. 2002). As suspension feeders, they have a significant influence on bentho-pelagic interactions, including impacts on primary production and concentrations of suspended particles (Petersen \& Riisgård 1992, Kowalke 1999). As sessile, soft-bodied organisms, ascidians are vulnerable to generalist predators including fish (Randall 1967), sea urchins (Briscoe \& Sebens 1988) and sea stars (Mauzey et al. 1968, McClintock et al. 2004) and specialist predators including select species of gastropods, including lamellarians and nudibranches (Cimino \& Ghiselin 2001) as well as several flatworms (de Caralt et al. 2002). Intense predation pressure on sessile marine invertebrates includ- ing ascidians has contributed to selection for a suite of defenses. For example, some marine invertebrates have developed mechanical means of deterring predators and fouling organisms. In sponges, physical defenses may include spicules (Chanas \& Pawlik 1995, 1996, Burns \& Ilan 2003) or sloughing off of surface layer tissues or mucus that is secreted on outer surfaces (Barthel \& Wolfrath 1989, Steinberg et al. 1997). Some colonial and, especially, solitary ascidians possess a tough outer tunic comprised of the proteinaceous polysaccharide tunicin. In some of these species, the tunic is further impregnated with minute spicules that may serve to deter some predators (Lambert \& Lambert 1987, López-Legentil et al. 2006). Nonetheless, the primary provision for protection from predators in ascidians appears to be based on chemical defenses (Stoecker 1978, 1980, Davis 1991, McClintock et al. 1991, 
Lindquist et al. 1992, Pawlik 1993, Pisut \& Pawlik 2002, McClintock et al. 2004).

While both organic and inorganic chemicals may play a role in ascidian chemical defenses, many appear to be secondary metabolites. A wide variety of natural products have now been isolated from ascidians, primarily from tropical and temperate latitudes (Pawlik 1993, Faulkner 2002, Paul \& Puglisi 2004, Paul et al. 2006, Paul \& Ritson-Williams 2008). Only a small subset of ascidians with known secondary metabolites has been subjected to ecological studies. For example, Young \& Bingham (1987) tested the palatability of the larvae of the tropical colonial ascidian Ecteinascidia turbinata and demonstrated that larvae contained secondary metabolites that were unpalatable to the planktivorous pinfish Lagodon rhomboides. Lindquist \& Fenical (1991) described an alkaloid in the class tambjamine (tambjamine C) in both the larvae and adults of the tropical ascidian Sigillina cf. signifera that caused feeding deterrence in a suite of sympatric coral reef fish. Alkaloids (eudistomins) were also isolated from the tunic of the tropical colonial ascidian Eudistoma olivaceum (Davis \& Wright 1989); these alkaloids did not deter fish feeding, but were effective as antifoulants (Davis 1991). Larvae of the Caribbean ascidian Trididemnum solidum contain a variety of secondary metabolites which deter feeding in the pinfish L. rhomboides, as well as in the sea urchin Arbacia punctulata and the sea anemone Aiptasia pallida. The ascidian Sigillina cf. signifera was found to contain an alkaloid (tambjamine E) that deters feeding in 6 coral reef fishes (Lindquist et al. 1992). In a broad survey that encompassed 17 solitary and colonial ascidians from the Western Atlantic, 16 species were found to harbor secondary metabolites that were deterrent against the bluehead wrasse Thalassoma bifasciatum (Pisut \& Pawlik 2002). Most recently, López-Legentil et al. (2006) found the ascidian Cystodytes sp. from the Mediterranean and South Pacific contained an alkaloid (ascididemin) that deterred feeding in a suite of generalist fish predators but not in a sea urchin.

In addition to organic secondary metabolites, inorganic acids have also been shown to provide chemical defenses in ascidians (Parry 1984, Davis \& Wright 1989, Pawlik 1993, Pisut \& Pawlik 2002). A number of species sequester sulfuric acid on their tunic surfaces or in special acid-filled surface bladder cells. These acids have been implicated both in the provision of antifoulant activity (Davis \& Wright 1989) as well as serving as antifeedants (Pisut \& Pawlik 2002). While there has been some suggestion that acids would be rapidly neutralized in seawater (Parry 1984), recent studies have demonstrated that their deterrent properties are retained for a period of time sufficient to deter ecologically relevant predators (Pisut \& Pawlik 2002, McClintock et al. 2004).
Perhaps even more so than in temperate and tropical marine environments, ascidians are ecologically dominant members of Antarctic benthic communities (Ramos-Espla et al. 2005). At shallow depths (<30 m), the Antarctic benthos can be greatly influenced by anchor ice and ice scour that produce distinct zonation patterns in community structure (Dayton et al. 1969, 1974, Sahade et al. 1998). Ascidians appear to be able to withstand such physical disturbances better than other sessile marine invertebrates. Moreover, their comparatively high growth rates allow them to effectively colonize recently disturbed habitats (Kowalke et al. 2001). In less physically disturbed areas, ascidians are able to numerically dominate in areas where competitive interactions are the determining factor in shaping the benthic community (Sahade et al. 1998). In shallow benthic communities of the Antarctic Peninsula, ascidians are often the dominant group of sessile marine invertebrates in terms of biomass, especially on soft sediments below depths of $15 \mathrm{~m}$ (Sahade et al. 1998, Tatian et al. 1998). In a study of the ascidian communities in the vicinity of Potter Cove, King George Island, along the western Antarctic Peninsula, Tatian et al. (1998) described 17 species of ascidians, mainly from the genera Pyura, Molgula and Sycozoa. The majority of the species (11) were solitary, while the remaining 6 were colonial. Also noted was that 7 of the solitary species were fouled, while all the colonial species were free of epibionts (Tatian et al. 1998). In a comprehensive comparative study, Ramos-Espla et al. (2005) found 172 species of ascidians occurring at depths ranging between 10 to $600 \mathrm{~m}$ along the Antarctic Peninsula, the Scotia Arc and the Magellan region. Likely predators of Antarctic ascidians include sea stars, fish and meso-crustaceans. Recent studies have indicated that the diverse amphipod communities are important grazers in the nearshore communities of the Antarctic Peninsula (Huang et al. 2007), and may include not only macroalgae but also sessile benthic invertebrates such as sponges and ascidians in their diets (C. Aumack unpubl. data).

Compared to tropical and temperate ascidians, almost nothing is known about the chemical ecology of polar ascidians (Avila et al. 2008). To date, only 2 Antarctic species have been investigated, the solitary form Cnemidocarpa verrucosa (McClintock et al. 1991) and the colonial form Distaplia cylindrica (McClintock et al. 2004). Both were found to be unpalatable to various predators and chemically defended. Thus in the present study our objectives were to evaluate the palatability of a representative suite of Antarctic ascidians to 2 common sympatric omnivorous predators, the fish Notothenia coriiceps and the sea star Odontaster validus. For those species that proved unpalatable to either predator, we evaluated whether the lack of pal- 
ability could be attributed to either organic or inorganic chemicals. We also examined the feeding deterrent properties of organic extracts of outer tissues of this suite of ascidians against the common omnivorous amphipod Gondogeneia antarctica.

\section{MATERIALS AND METHODS}

Field collections. Ascidians were collected by hand using SCUBA from depths ranging from 2 to $39 \mathrm{~m}$ from various locations within a $3.5 \mathrm{~km}$ radius of the US Palmer Station, Anvers Island, western Antarctic Peninsula $\left(64^{\circ} 46.5^{\prime} \mathrm{S}, 64^{\circ} 03.3^{\prime} \mathrm{W}\right)$. We did not select particular species of ascidians for inclusion in the present study, but rather examined all species we encountered, thus ensuring an unbiased sample of representative species. Collections were made February to June 2007 and March to June 2008. Freshly collected ascidians were subject to volume (by seawater displacement in a graduated cylinder) and wet weight determinations. Those individuals not used for fresh tissue palatability assays or for inorganic acid measurements were immediately frozen at $-80^{\circ} \mathrm{C}$ for later extraction of secondary metabolites (see below). Individuals of the sea star Odontaster validus were collected by hand using SCUBA from the same locations as the ascidians between February and May 2008. The fish Notothenia coriiceps were collected using hook and line, fish traps and occasionally by hand using SCUBA from within $1 \mathrm{~km}$ of Palmer Station. Individuals of the amphipod Gondogeneia antarctica were collected using SCUBA by first collecting individuals of the alga Desmarestia menziesii using fine mesh bags (Huang et al. 2007). When returned to the laboratory, the algae were repeatedly submerged in seawater in buckets, then the bucket contents sieved and individuals of G. antarctica sorted and held alive in 21 plastic bottles equipped with holes fitted with fine wire mesh to allow seawater exchange when floated in a flow-through seawater tank.

Inorganic acid $(\mathrm{pH})$ measurements of outer tunic. The presence of inorganic acid (sulfuric acid; Webb 1939, Levine 1961, Stoecker 1980) on the outer tunic surfaces of the targeted suite of solitary and colonial ascidians was determined using analytical $\mathrm{pH}$ strips (EM ColorpHast). Tunic surface $\mathrm{pH}$ measurements were conducted using first a $\mathrm{pH}$ strip with a range of 0 to 14 and a resolution of $1 \mathrm{pH}$ unit. Once an initial pH was determined, a more narrow resolution of $\mathrm{pH}$ was determined by using the appropriate $\mathrm{pH}$ strip for this range of $\mathrm{pH}$ values, with more highly refined increments of 0.2 to $0.3 \mathrm{pH}$ units. Because the test was subjective due to $\mathrm{pH}$ being determined by matching strip color to a color chart, we chose to be conservative by rounding the $\mathrm{pH}$ measurement to the nearest 0.5 unit.
All pH strip measurements were made by removing ascidians from seawater and then placing the $\mathrm{pH}$ strip against the 'dry' outer tunic for a period of $5 \mathrm{~min}$.

Preparation of ascidian organic extracts for feeding bioassays. Organic extracts of ascidians were prepared using whole colonies of colonial ascidians and whole individuals of solitary forms. The general extraction process follows techniques described in McClintock et al. (2004). Several colonies or individuals were weighed, lyophilized and then re-weighed. The freeze-dried tissues were then extracted thrice in dichloromethane/methanol (1:1 ratio) for $24 \mathrm{~h}$. Extracts were combined and filtered through a coarse filter paper and dried down using rotary evaporation to yield a lipophilic extract. A hydrophilic extract was prepared by subsequent extraction of the same freezedried tissue using methanol/water (1:1 ratio) thrice for $24 \mathrm{~h}$. Both lipophilic and hydrophilic extracts were weighed following drying. The natural concentrations of extracts for bioassays were calculated on a volumetric basis as mass of extract per unit volume.

Sea star bioassays: ascidian fresh tissue, organic extracts and inorganic acids. Sea star feeding bioassays were performed using protocols developed by McClintock \& Baker (1997a). The sea star Odontaster validus was selected because it is an abundant, omnivorous predator (Dayton et al. 1974, McClintock et al. 1988, 2004, McClintock 1994). Moreover, it is frequently seen preying on sessile benthic macroinvertebrates in the vicinity of Palmer Station (authors' pers. obs.). Sea stars were held in a large, circular, flow-through seawater tank (1.8 $\mathrm{m}$ diameter $\times 0.9 \mathrm{~m}$ height) equipped with ambient seawater $\left(1^{\circ} \mathrm{C}\right)$. When held in a tank, $O$. validus tend to climb vertically and position themselves at the air-water interface with several of their arms stretched out such that their ambulacral grooves are exposed upwards (McClintock et al. 2004).

Small pieces (approximately $0.5 \mathrm{~cm}^{3}$ ) of the outer tissues of ascidians were prepared from freshly collected individuals. During the feeding trials described below, the small pieces of tissue were presented to sea stars such that the outer surface of the tunic was facing the outstretched tube feet within the ambulacral groove of an upward-facing arm.

Artificial food pellets were prepared in a matrix of $2 \%$ alginate containing $2 \%$ dry weight krill powder as a feeding stimulant (McClintock \& Baker 1997a). Extracts were dissolved in the minimum amount of the solvent used in their initial extraction (see above) and dried onto the krill powder using a rotary evaporator (Hay et al. 1994). Control pellets were prepared using the same amount of solvent dried onto krill powder. A second set of control pellets was prepared with alginate pellets that contained only krill powder but no solvent. Both experimental and control treatment krill 
powders were placed into $10 \mathrm{~cm}$ diameter Petri dishes. Alginate solution was then added to the dishes and thoroughly mixed. A cold solution of $1 \mathrm{M} \mathrm{CaCl}_{2}$ was subsequently poured over the mixture causing immediate gelling. Triangular alginate pellets $(0.3 \mathrm{~cm}$ per side) were then prepared using a single-edged razor blade.

During the sea star feeding trials, 12 to 16 individuals (3 to $6 \mathrm{~cm}$ radius) were presented with either a piece of fresh ascidian tissue or a food pellet containing the hydrophilic or lipophilic ascidian extract from a species that was rejected in fresh tissue assays. In the case of fresh tissues, each sea star was subsequently presented a non-solvent control food pellet. In the case of the food pellets containing extracts, first a series of feeding assays was performed whereby sea stars were offered a pellet containing extract followed by a nonsolvent control food pellet as a satiation control. A second set of sea stars were offered solvent control food pellets followed by a non-solvent satiation control food pellet. In all of the above, the food item was placed in the ambulacral groove in the middle of the arm, equidistant between the arm tip and the mouth. Acceptance (movement of the fresh tissue or pellet towards the mouth and extrusion of the cardiac stomach) or rejection (movement of the fresh tissue or pellet away from the mouth, or displacement from the ambulacral groove) was recorded over a 20 min period. Differences between acceptance of tissue or pellets and the corresponding controls were determined using a Fisher's exact test (Sokal \& Rohlf 2001). For fresh tissue pieces, the controls used in statistical comparisons were the non-solvent food pellets. For pellets containing ascidian extracts, the controls were the corresponding solvent-treated control pellets that were offered to a different set of sea stars (Amsler et al. 2005).

The ability of inorganic acids to deter feeding in the sea star Odontaster validus was examined using agar pellets, as alginate does not gel under acidic conditions. Agar food pellets were prepared by mixing 1\% agar in seawater and $2 \%$ dry krill powder as a feeding stimulant. The pellets were then acidified by adding drops of $1.0 \mathrm{~N} \mathrm{H}_{2} \mathrm{SO}_{4}$ to the liquid agar containing the krill powder until the $\mathrm{pH}$ was reduced to the desired level. The solution was then poured into $10 \mathrm{~cm}$ diameter Petri dishes. Triangular alginate pellets $(0.2 \mathrm{~cm}$ per side) were then cut using a single-edged razor blade. Acidified agar pellets were prepared at $\mathrm{pH}$ values of 2, 3, 4, 5 and 6 (Pisut \& Pawlik 2002, McClintock et al. 2004). The $\mathrm{pH}$ of the acidified pellets was tested using $\mathrm{pH}$ strips as mentioned above. Control pellets consisted of agar pellets prepared at a neutral $\mathrm{pH}$ of 7 . In order to ensure that pellets retained their acidity over the time-course of the sea star and fish bioassays (see below), 5 pellets acidified to each test $\mathrm{pH}$ were submerged in seawater at the temperature used in feeding experiments for a period of $1 \mathrm{~min}$ and then their $\mathrm{pH}$ levels measured using $\mathrm{pH}$ strips. All pellets were found to retain their initial $\mathrm{pH}$ level after this time period.

Feeding assays were conducted beginning at the lowest $\mathrm{pH}_{\text {, }}$ and followed the feeding procedure described above. Briefly, each sea star was offered a control agar food pellet. If accepted, the sea star was then subsequently offered an acidified experimental pellet and acceptance or rejection recorded. Differences between acceptance of control and treated pellets were analyzed using a Fisher's exact test. In this assay, and in the fresh tissue and organic extract feeding assays, no individual sea star was used more than once in a given treatment.

Fish bioassays: ascidian fresh tissue, organic extracts and inorganic acids. The Antarctic fish Notothenia coriiceps was used in ascidian feeding assays. This fish is an abundant, omnivorous predator that occurs along the Antarctic Peninsula (Blankley 1982, BarreraOro \& Casaux 1990, Casaux et al. 1990, Iken et al. 1997). Individual fish (length approximately 20 to $30 \mathrm{~cm})$ were held in either a seawater table $(1 \times 2 \times$ $0.25 \mathrm{~m}$ depth and divided into 3 equal-sized compartments using fine-mesh dividers), or in individual tanks $(0.6 \times 0.6 \times 0.6 \mathrm{~m})$. Both the water table and tanks were equipped with flowing ambient seawater at $1^{\circ} \mathrm{C}$. Initially, fish were maintained on a diet of limpet tissue (whole tissues of 2 Nacella concinna with shell length $\sim 3$ to $5 \mathrm{~cm}$ per fish per day) proffered to them by hand on the tip of $20 \mathrm{~cm}$ forceps. Fish learned within 5 to $7 \mathrm{~d}$ to associate the approaching forceps with food, and were then switched to a diet comprised of alginate pellets that contained $3.25 \%$ alginate and $5 \%$ dried krill powder for a period of $3 \mathrm{~d}$ (see pellet preparation techniques above). In all fish feeding trials described below, this level of alginate and krill powder was used to prepare pellets following techniques described above.

In fish bioassays, 9 to 14 individuals were offered either a piece of fresh tissue $\left(1 \mathrm{~cm}^{3}\right)$ or a circular alginate food pellet $(2 \mathrm{~cm}$ diameter $\times 2 \mathrm{~mm}$ depth) containing either a hydrophilic or lipophilic ascidian extract from a species that was rejected in fresh tissue assays. After being presented with the fresh tissue or alginate food pellet, each fish was subsequently presented with a control alginate food pellet containing krill powder but no extract. Individual fish were used in no more than one feeding trial for each of the 3 treatments (fresh tissue, hydrophilic extract, lipophilic extract), with at least $6 \mathrm{~h}$ allowed between a given feeding trial. An acceptance response was recorded when a fish swallowed the tissue or pellet with no subsequent regurgitation. A rejection response was recorded when a fish mouthed the tissue or pellet and subsequently 
immediately spat it out. Controls for fresh ascidian tissues consisted of non-solvent alginate food pellets. Similar to sea star feeding assays, controls for the ascidian extract food pellets were the appropriate solvent-treated food pellet. Differences between consumption of fresh ascidian tissues or pellets with ascidian extracts and their corresponding controls were analyzed using Fisher's exact test.

The ability of inorganic acids to deter fish feeding was investigated using similar agar pellet preparation techniques as given for sea stars above, with the exception of preparing pellets at a concentration of $5 \%$ dry weight krill powder. However, upon the completion of feeding trials using the lowest $\mathrm{pH}$ alginate food pellets tested ( $\mathrm{pH} 2)$, it became evident that fish were not deterred from consuming pellets at this very low $\mathrm{pH}$. Thus testing for feeding deterrent properties of pellets food acidified at higher $\mathrm{pH}$ values was not conducted.

Amphipod bioassays. Artificial food pellets containing hydrophilic and lipophilic organic extracts of 10 of the ascidian species were bioassayed with the common omnivorous amphipod Gondogeneia antarctica (Huang et al. 2006, 2007). Measurements of rates of amphipod consumption of fresh tissue were not feasible due to the lengthy time required for measurable consumption. Similarly, measurements of the consumption of acidified agar food pellets by amphipods exceeded the period of time these pellets retained their acidity.

Amphipod feeding assays using alginate pellets were conducted using a 2-choice feeding assay model (Peterson \& Renaud 1989, Amsler et al. 2005). In each assay, an alginate pellet (disc-shaped, $1 \mathrm{~cm}$ diameter, $2 \mathrm{~mm}$ thick) prepared with $2 \%$ alginate and containing a $2 \%$ dried krill powder and either a hydrophilic or lipophilic ascidian extract was paired with a control alginate pellet containing solvent-only treated krill powder. These were placed together into a sealed $250 \mathrm{ml}$ bottle and floated in flow-through seawater tanks $\left(1^{\circ} \mathrm{C}\right)$. Twenty haphazardly selected adult individuals of the amphipod G. antarctica were placed into 10 bottles, while a second set of 10 bottles contained pellets but no amphipods, to serve as an autogenic control for changes in the mass of the pellets (e.g. due to water gain). The feeding experiments ran for a period of 48 to $96 \mathrm{~h}$, until a noticeable change in the mass of the alginate food pellets was observed. Fresh seawater was replaced in each bottle every $24 \mathrm{~h}$. Pellets were then removed from each bottle, blotted gently with a tissue to remove excess seawater and weighed. Feeding deterrence was evaluated by calculating the differences in wet weight pre- and postexperiment of the control and treatment pellets corrected by the autogenic controls and treatments using a Wilcoxon signed-ranked test.

\section{RESULTS}

\section{Outer tunic acidity}

$\mathrm{pH}$ values for the outer surfaces of the tunic of 6 solitary and 8 colonial species of ascidians ranged from 1.5 to 8.0 (Table 1). High levels of acidity (defined as $\mathrm{pH}<4$ ) detected on the outer body surface were more common in colonial ascidians ( 4 of 8 species) than in solitary ascidians ( 1 of 6 species).

Table 1. Antarctic ascidans examined including their taxonomic classification, body organization, surface pH of the tunic and the specific feeding deterrent bioassays (fresh tissue or organic extracts) performed against sea stars (S), fish (F) or amphipods (A). +/-: bioassay performed/not performed

\begin{tabular}{|c|c|c|c|c|c|c|c|c|c|c|}
\hline \multirow[t]{2}{*}{ Species } & \multirow[t]{2}{*}{ Family } & \multirow[t]{2}{*}{ Order } & \multirow[t]{2}{*}{ Organization } & \multirow[t]{2}{*}{$\mathrm{pH}$} & \multicolumn{3}{|c|}{ Fresh tissue } & \multicolumn{3}{|c|}{ Organic extracts } \\
\hline & & & & & $\mathrm{F}$ & $\mathrm{S}$ & $\mathrm{A}$ & $\mathrm{F}$ & $\mathrm{S}$ & $\mathrm{A}$ \\
\hline Trididemnum sp. $^{\mathrm{a}}$ & Didemnidae & Aplousobranchia & Colonial & 2.5 & - & - & - & - & - & - \\
\hline Didemnum biglans & Didemnidae & Aplousobranchia & Colonial & 7 & + & + & - & + & + & + \\
\hline Distaplia cylindrica & Holozoidae & Aplousobranchia & Colonial & 2 & + & + & - & + & + & + \\
\hline Distaplia colligans & Holozoidae & Aplousobranchia & Colonial & 1.5 & + & + & - & + & + & + \\
\hline Sycozoa gaimardii & Holozoidae & Aplousobranchia & Colonial & $1.5-2.0$ & + & + & - & - & - & - \\
\hline Aplidium sp. & Polyclinidae & Aplousobranchia & Colonial & 7 & - & - & - & + & + & + \\
\hline Synoicum adareanum & Polyclinidae & Aplousobranchia & Colonial & 7.5 & + & + & - & + & + & + \\
\hline Synoicum sp. & Polyclinidae & Aplousobranchia & Colonial & 7 & + & + & - & + & + & + \\
\hline Ascidia sp. & Ascidiidae & Phlebobranchia & Solitary & 7 & + & + & - & + & + & + \\
\hline Corella eumyota & Corellidae & Phlebobranchia & Solitary & 2 & + & + & - & + & + & + \\
\hline Microcosmos sp. & Pyuridae & Stolidobranchia & Solitary & 7 & + & + & - & + & + & + \\
\hline Pyura georgiana & Pyuridae & Stolidobranchia & Solitary & 7 & + & + & - & + & + & + \\
\hline Pyura setosa & Pyuridae & Stolidobranchia & Solitary & 7 & + & + & - & + & + & + \\
\hline Cnemidocarpa verrucosa & Styelidae & Stolidobranchia & Solitary & 8 & + & + & - & + & + & + \\
\hline
\end{tabular}


Fresh ascidian tissue bioassays with sea stars and fish

Twelve of the 14 species of ascidians were assayed in fresh tissue bioassays with sea stars and fish (an insufficient amount of Aplidium sp. limited this species to tests of organic extracts only). Seven of these twelve species $(64 \%)$ were significantly unpalatable ( $p<0.01$ ) to the sea star Odontaster validus, of which 5 species $(71 \%)$ had colonial organization and 2 species $(29 \%)$ had solitary organization (Fig. 1). All fresh body tissues from the 12 species of ascidians were significantly ( $\mathrm{p}<0.01)$ unpalatable to the fish Notothenia coriiceps (Fig. 1).

\section{Organic extract bioassays with sea stars, fish and amphipods}

Natural concentrations for hydrophilic and lipophilic organic extracts of the 14 species of ascidians ranged from 6.3 to 70.3 and 10.7 to $42.5 \mathrm{mg}$ DW extract per ml wet ascidian tissue, respectively (Table 2). Extracts of the ascidian Sycozoa gaimardi were not tested as there was insufficient biomass available for extraction. Of the 7 species that were unpalatable to the sea star Odontaster validus, and thus tested as extracts, the lipophilic extract of the colonial Distaplia colligans was a significant deterrent ( $p<0.0001)$ (Fig. 2). Similarly, among the 12 species of ascidians that proved to be unpalatable to the fish Notothenia coriiceps, the lipophilic extract of $D$. colligans was a significant deterrent ( $\mathrm{p}=0.0062)$ (Fig. 3).

When hydrophilic and lipophilic extracts of 10 ascidian species were assayed against the amphipod Gondogeneia antarctica, only the lipophilic extract of the colonial Distaplia cylindrica was a significant deterrent ( $p=0.047$ ) (Fig. 4). In 8 of the 10 ascidian species, pellets containing extracts were consumed in significantly $(\mathrm{p} \leq 0.05)$ greater quantities than control pellets (Fig. 4).

\section{Inorganic acids: feeding bioassays}

Agar food pellets acidified to $\mathrm{pH} 2,3,4$ and 5 were significant deterrents $(p<0.05)$ to the sea star Odon-

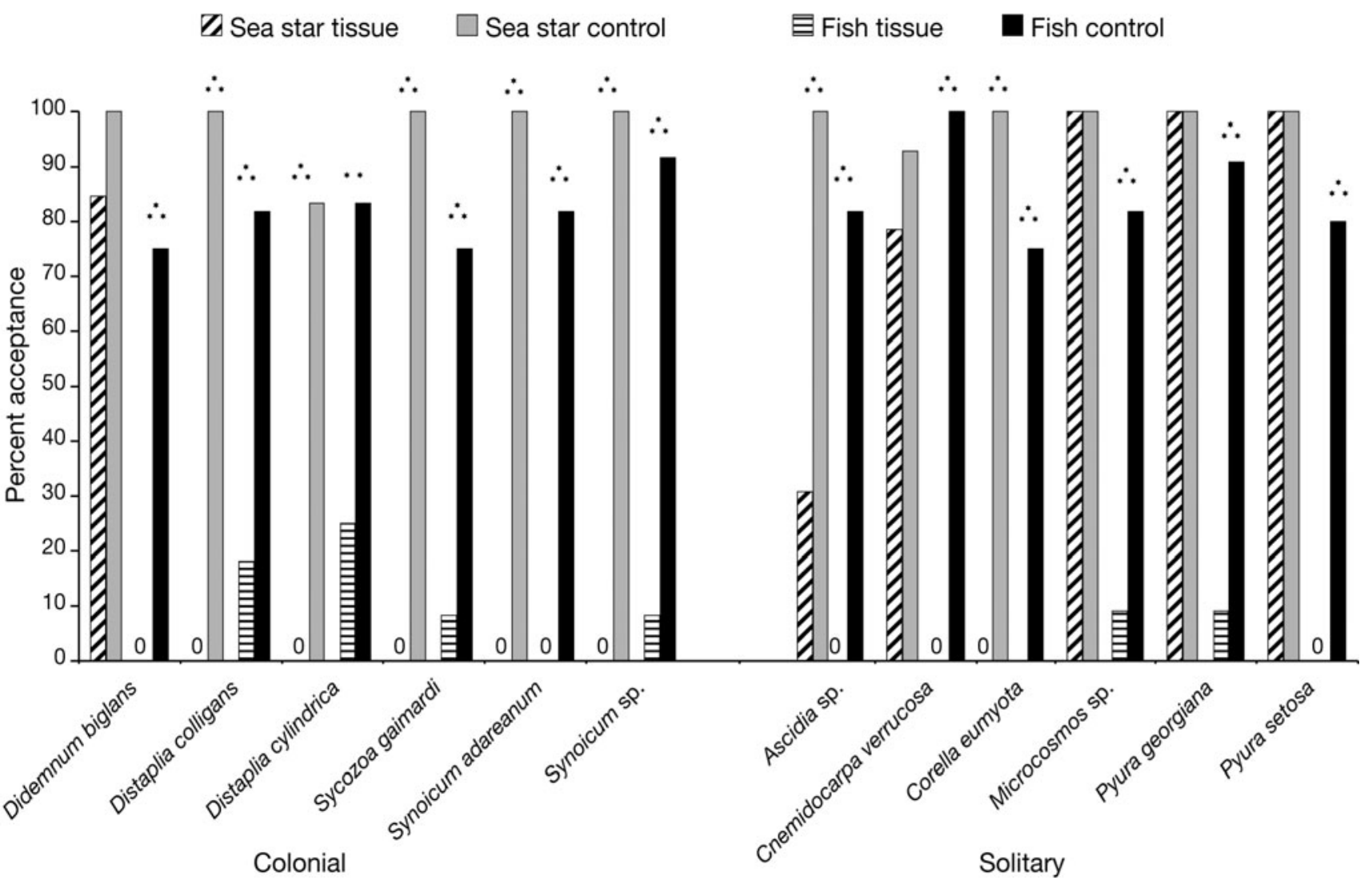

Fig. 1. Odontaster validus and Notothenia coriiceps. Results of bioassays offering pieces of ascidian tunic tissue to the sea star $O$. validus and the fish $N$. coriiceps. Asterisks indicate significant difference between tissue and control (Fisher's exact test). ${ }^{* *} \mathrm{p} \leq$ $0.01 ;{ }^{* * *} \mathrm{p} \leq 0.005$. Ascidians are listed in alphabetical order from left to right, with the first group representing colonial and the second solitary species (same pattern shown in Figs. 2-4) 
Table 2. Volumetric extract yields (the natural concentration of an extract) expressed as mg dry extract per ml wet ascidian tissue. WW: wet weight; DW: dry weight; Vol: volume; n/a: not available

\begin{tabular}{|c|c|c|c|c|}
\hline \multirow{2}{*}{ Species } & \multicolumn{2}{|c|}{ Volumetric extract yields } & \multicolumn{2}{|c|}{ Ratio } \\
\hline & Lipophilic & Hydrophilic & WW:DW & WW:Vol \\
\hline Trididemnum sp. & 20.4 & 39.8 & 8.72 & 1.72 \\
\hline Didemnum biglans & 19.9 & 28.2 & 11.36 & 1.02 \\
\hline Distaplia cylindrica & 18.3 & 18.5 & 23.09 & 1.04 \\
\hline Distaplia colligans & 42.5 & 70.3 & $\mathrm{n} / \mathrm{a}$ & 1.11 \\
\hline Sycozoa gaimardii & 26.2 & 6.3 & 17.63 & 1.17 \\
\hline Aplidium sp. & 14.6 & 25.4 & 9.92 & 1.02 \\
\hline Synoicum adareanum & 10.7 & 24.2 & 16.86 & 1.03 \\
\hline Synoicum sp. & 12.5 & 21.9 & 12.74 & 1.00 \\
\hline Ascidia sp. & 11.2 & 24.7 & 13.37 & 1.04 \\
\hline Corella eumyota & 26.0 & 8.0 & 20.35 & 1.02 \\
\hline Microcosmos sp. & 11.2 & 19.3 & 14.17 & 0.98 \\
\hline Pyura georgiana & 23.2 & 19.3 & 10.17 & 1.04 \\
\hline Pyura setosa & 14.8 & 19.3 & 7.13 & 0.95 \\
\hline Cnemidocarpa verrucosa & 14.5 & 20.5 & 16.30 & 0.98 \\
\hline
\end{tabular}

taster validus in feeding assays (Fig. 5). In contrast, there was no significant deterrence detected when sea stars were presented agar food pellets acidified to $\mathrm{pH} 6$ or neutral $\mathrm{pH} 7$. Acidified pellets ( $\mathrm{pH} 2$ to 5) invoked an immediate behavioral response in sea stars ( $<1 \mathrm{~min})$ consisting of rapid retraction of the tube feet making contact with the pellet, subsequent removal of the pellet from the ambulacral groove and pellet dropping, and then movement of the entire individual away from their resting position at the air-water interface of the tank.

Agar food pellets acidified to $\mathrm{pH} 2$ were all readily consumed by the fish Notothenia coriiceps. As there was no deterrence, feeding assays with pellets acidified to higher $\mathrm{pH}$ values were not necessary.

\section{DISCUSSION}

The 3 contrasting predators examined in the present study (sea stars, fish and amphipods) each elicited different patterns of feeding deterrent responses to Antarctic ascidians. Odontaster validus is a common omnivorous sea star predator that feeds on a highly diverse assemblage of benthic marine invertebrates (McClintock 1994). Sea stars rejected 7 of the 12 ascidian species that were presented to them as fresh tissue, accepting tissues of the other 5 species. Of the 7 species that lacked palatability, 5 were colonial and 2 had solitary organization. Rejection of 4 of the 7 species that proved unpalatable as fresh tissue was attributable to a chemical defense. The colonial ascidian Distaplia colligans was protected from sea star predation by secondary metabolites in its lipophilic extract as well as by inorganic acids sequestered on the outer surface of its tunic. An additional 3 ascidian species (Distaplia cylindrica, Sycozoa gaimardi and Corella eumyota) had surface acidity at levels unpalatable to $O$. validus via inorganic acids (sulfuric acid) sequestered on the outer surfaces of their tunics. In the present study, O. validus was deterred from consuming alginate food pellets when pellets had a $\mathrm{pH}$ of 5 or less. Trididemnum sp. was only tested for acidity and was not used in the bioassays; however, it is presumed that its surface $\mathrm{pH}$ of 2.5 will also deter predation by $O$. validus.

McClintock et al. (2004) similarly examined the response of the sea star Odontaster validus to acidified

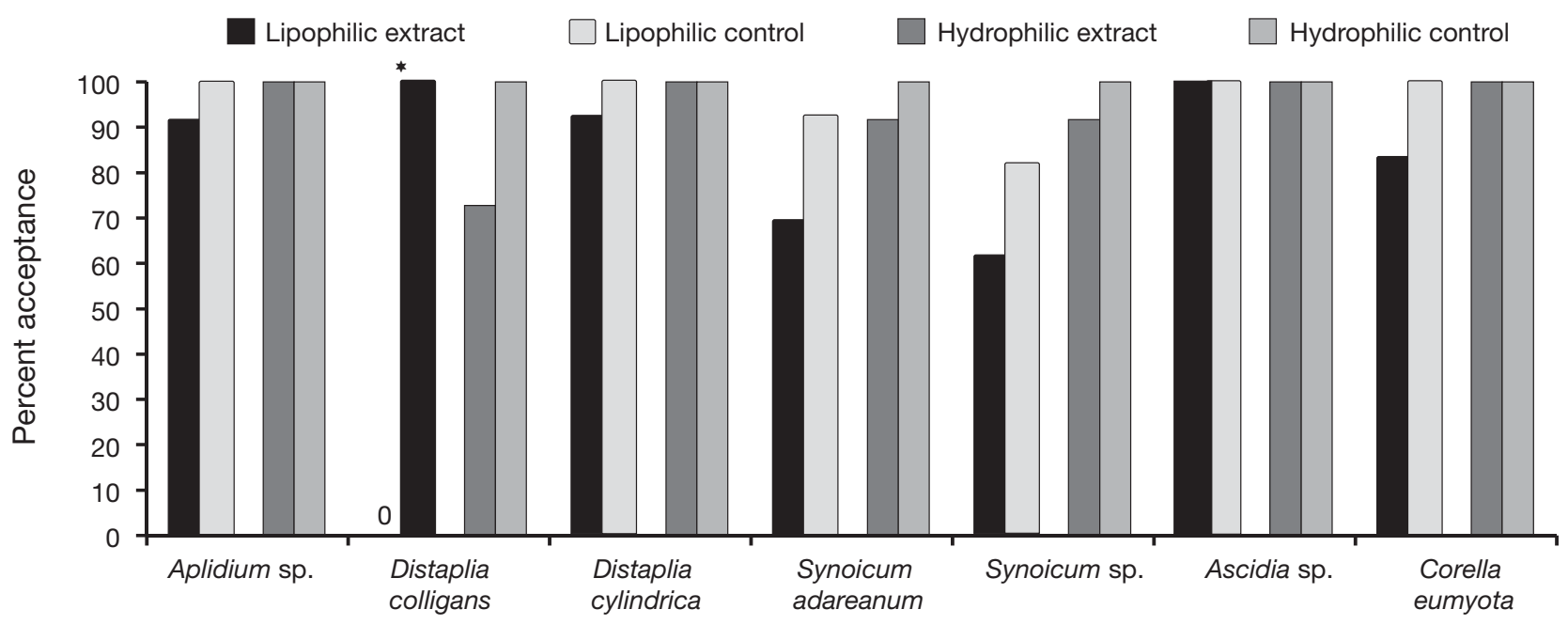

Fig. 2. Odontaster validus. Results of bioassays offering artificial foods containing lipophilic or hydrophilic ascidian extract to sea stars. Asterisks indicate significant difference between tissue and control (Fisher's exact test). ${ }^{*} \mathrm{p} \leq 0.05$ 


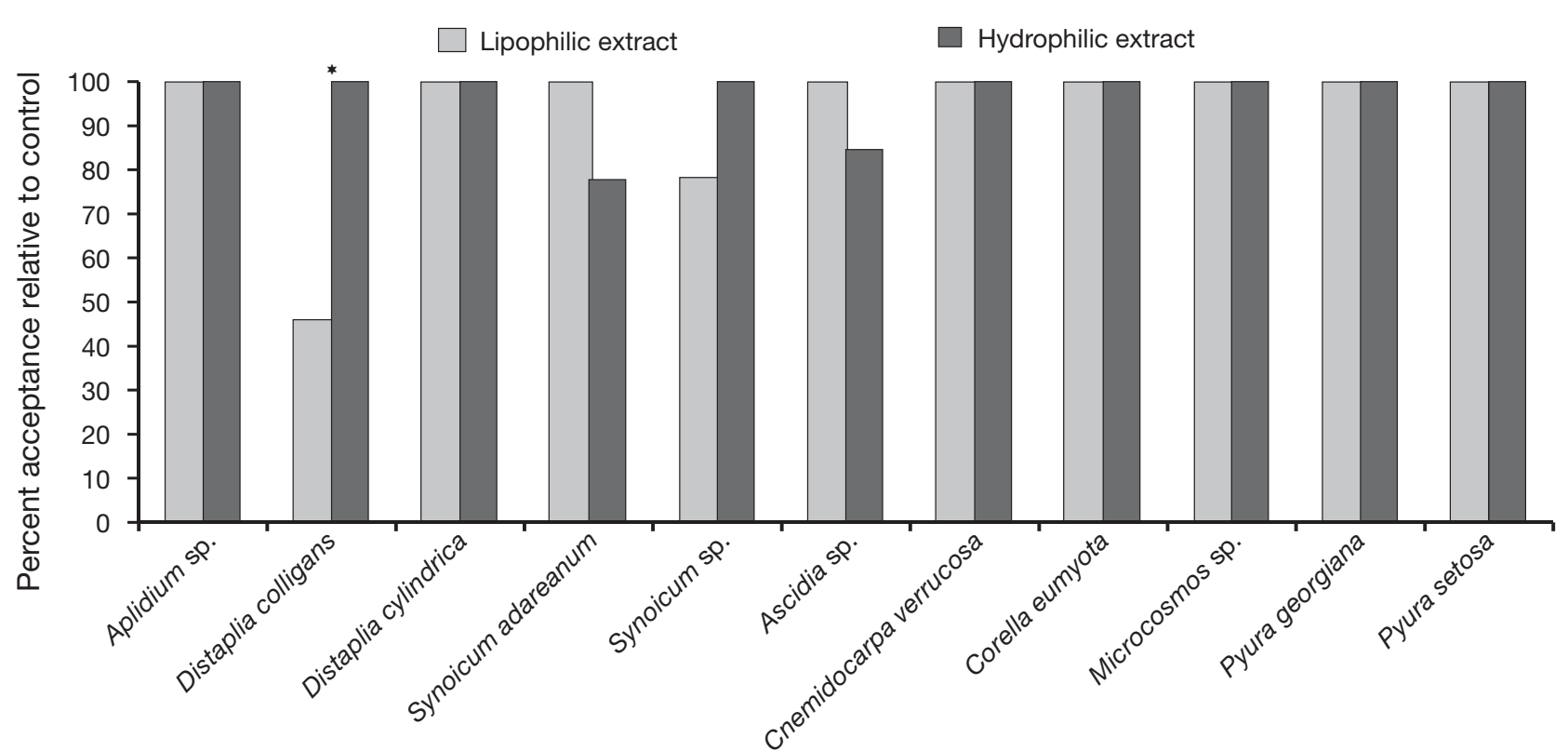

Fig. 3. Notothenia coriiceps. Results of bioassays offering artificial foods containing lipophilic or hydrophilic ascidian extract to fish. Asterisks indicate significant difference between tissue and control (Fisher's exact test). ${ }^{*} \mathrm{p} \leq 0.05$

food pellets and demonstrated feeding deterrence at natural $\mathrm{pH}$ levels that occur on the outer tunic of Distaplia cylindrica. As O. validus feeds by extruding its cardiac stomach and laying it against the outer surface of large sessile prey (e.g. sponges, McClintock 1994), inorganic acids that are sequestered on the outer tunic surface may be particularly effective against the thin, exposed, sensitive tissues of the cardiac stomach (Day- ton et al. 1974, McClintock 1994). Moreover, sea star tube feet are highly chemosensory, allowing them to perceive and evaluate potential prey and their defensive attributes (Sloan 1980a,b, Sloan \& Campbell 1982, McClintock et al. 1984, 1994). When presented acidified krill pellets, the sensory tube feet retract along the ambulacral groove, indicative of a strong deterrent response (McClintock et al. 2000).

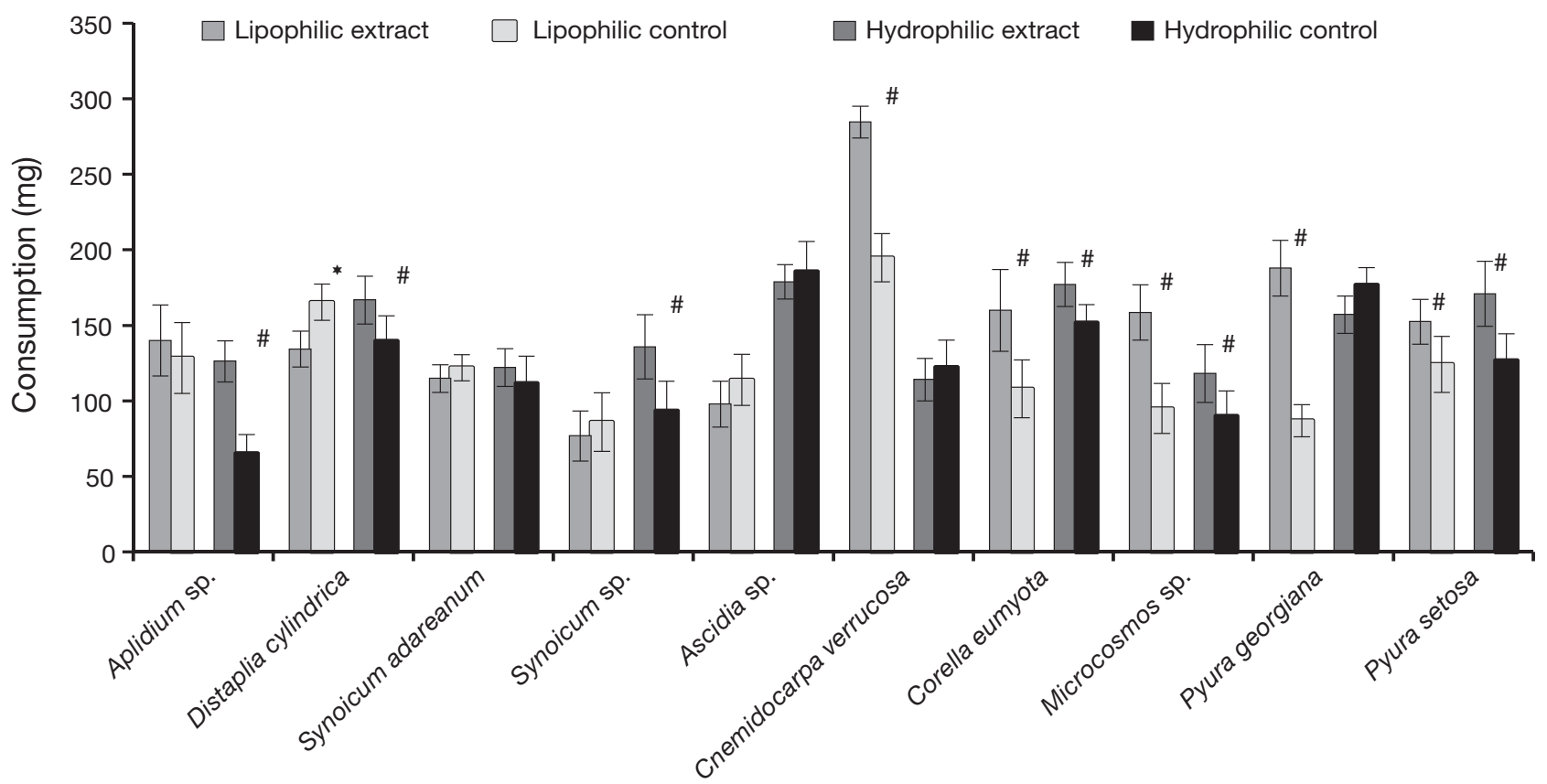

Fig. 4. Gondogeneia antarctica. Results of bioassays offering artificial food containing lipophilic or hydrophilic ascidian extract to amphipods. Values are means \pm SEM. Asterisks indicate significant difference between extract and control (Wilcoxon signedrank test) with controls significantly preferred to extract. ${ }^{*} \mathrm{p} \leq 0.05$. \#: Significant differences ( $\left.\mathrm{p} \leq 0.05\right)$ between extract and control (Wilcoxon signed-rank test), with extract significantly preferred to controls 


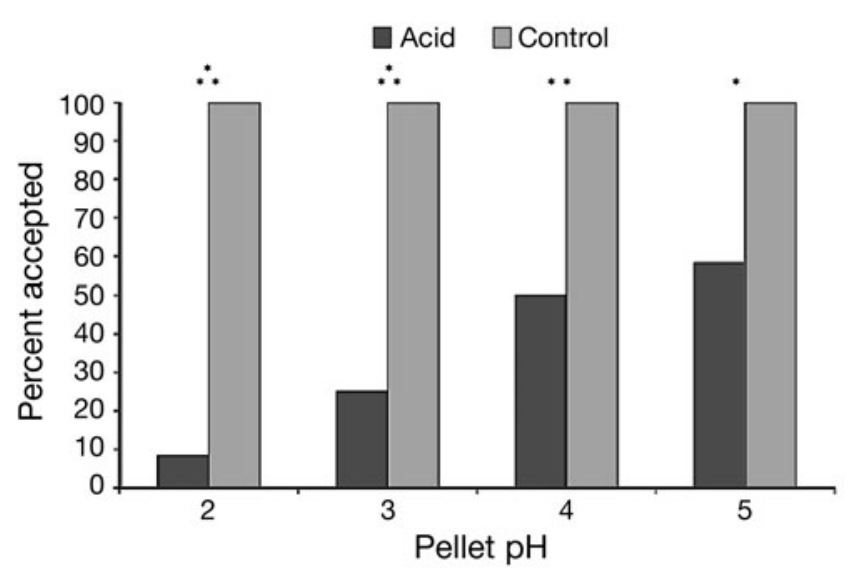

Fig. 5. Odontaster validus. Results of bioassays offering agar food pellets containing a $2 \%$ krill powder and acidified with sulfuric acid. Asterisks indicate significant difference between tissue and control (Fisher's extact test). ${ }^{*} \mathrm{p} \leq 0.05{ }^{*}{ }^{* *} \mathrm{p} \leq 0.01$; ${ }^{* * *} \mathrm{p} \leq 0.005$

It is intriguing that $80 \%$ (4 of 5 species) of the Antarctic ascidians that may employ inorganic chemical defenses against sea star predation were colonial rather than solitary forms. Moreover, qualitative observations indicated that solitary Antarctic ascidians appeared to have tougher, more protective, outer tunics than colonial forms, and thus colonial forms may be under greater selective pressure to employ chemical defenses. Similarly, Pisut \& Pawlik (2002) examined 17 species of common ascidians in the Caribbean and found that the majority (6 of 9 species) that employed sulfuric acid as a chemical defense against fish were colonial, rather than solitary, forms. McClintock et al. (2004) found that inorganic acid feeding deterrent properties of Distaplia cylindrica were complemented by lipophilic secondary metabolite(s) against the sea star Odontaster validus. Similar bioactivity was not detected against $O$. validus in the lipophilic extract of this ascidian in the present study. This suggests that D. cylindrica may have the capacity to display temporal or local geographic variation in the production of secondary metabolite defenses, as seen in soft corals (Harvell et al. 1993).

The common benthic fish Notothenia coriiceps exhibited strong and consistent rejection of fresh tissues of all 12 species of ascidians. This lack of palatability, however, was in large part not chemically mediated, as alginate pellets containing tissue level concentrations of organic extracts were, with the exception of the lipophilic extract of the colonial ascidian Distaplia colligans, readily consumed by the fish. Moreover, in contrast to sea stars, acidified agar krill pellets were readily consumed by fish, even at a highly acidic $\mathrm{pH}$ of 2, with no apparent ill effects post-consumption.
The diet of Notothenia coriiceps includes a wide variety of foods, including macroalgae as well as gastropods, amphipods, polychaetes and krill (BarreraOro \& Casaux 1990, Iken et al. 1997, 1999). Although not a common food item, this fish species has been known to occasionally include ascidians in its diet (Barrera-Oro \& Casaux 1990). In the present study, the general lack of palatability of pieces of outer fresh tissue of ascidians for this fish might be attributed to several factors. Kühne (1997) and Kowalke et al. (2001) suggest that low nutritional value of some solitary Antarctic ascidians may contribute to their unattractiveness as prey. However, it can be argued that Antarctic ascidians, both solitary and colonial, possess a nutritional value that does not differ significantly from other benthic sessile prey (e.g. sponges) readily consumed by predators such as sea stars (McClintock et al. 1991, 2004). Certainly macroalgae, one of the common food items of $N$. coriiceps, are likely to possess a lower nutritional value than ascidian prey. The solitary Antarctic ascidian Cnemidocarpa verrucosa, whose tissues proved to be unpalatable to $N$. coriiceps in the present study and to 2 additional Antarctic fish, Patagothenia borchgrevinki and Trematomus bernacchii, in a previous study (McClintock et al. 1991), has outer tissues (tunic) that possesses a relatively high energy content (McClintock et al. 1991). That fresh outer tissues of $C$. verrucosa were accepted as prey by the extraoral feeding sea star Odontaster validus suggests that the lack of palatability of the outer tissue of this ascidian to fish, a biting predator, is likely related to the toughness of the tunic.

The amphipod Gondogeneia antarctica is an omnivorous mesograzer that includes both plant and animal foods in its diet (approximately 30\% of its diet is comprised of invertebrate prey, C. Aumack unpubl. data). This amphipod occurs in extremely high densities (estimated densities of up to 1660 ind. $\mathrm{m}^{-2}$ benthos, based on calculations using estimates from Huang et al. 2007 and Amsler et al. 2008) along the central western Antarctic Peninsula. This amphipod has been used as a model mesograzer in studies of the chemical feeding deterrent properties of Antarctic macroalgae (Amsler et al. 2005) and sponges (Amsler et al. in press). The preference of this amphipod for pellets containing organic extracts of marine algae or sessile invertebrates is a phenomenon commonly observed in this species (Amsler et al. 2005, in press) and attributed to extracts being phagostimulatory.

Despite the methodological limitations that prevented us from testing fresh tissues or acidified food pellets against this common mesograzer, it is noteworthy that, similar to our findings for sea stars and fish, it is the lipophilic extract of the ascidian genus Distaplia that is the feeding deterrent to amphipods. This not 
only reflects broad spectrum of secondary metabolites in this genus in Antarctica, but indicates that secondary metabolite defenses are relatively rare among Antarctic ascidians. In contrast, the literature on tropical and temperate ascidians suggests secondary metabolite feeding deterrents are more common (Young \& Bingham 1987, Lindquist \& Fenical 1991, Lindquist et al. 1992, Pisut \& Pawlik 2002, López-Legentil et al. 2006).

The present study provides additional information relevant to the long-standing debate about the role of inorganic acids in the provision of defenses against predation in ascidians (Parry 1984, Davis \& Wright 1989, Pawlik 1993, Pisut \& Pawlik 2002). Stoecker $(1978,1980)$ concluded that sulfuric acid in the tunics of Aplousobranch and Phlebobranch ascidians deterred potential predators and inhibited fouling. Hirose $(1999,2001)$ examined the tunics of several solitary and colonial ascidians and reported that upon injury, acid-filled bladder cells burst, releasing their contents. He proposed this facilitated predator deterrence as well as disinfecting the injured area. Nonetheless, Parry (1984) argued that inorganic acids in ascidians cannot be anti-predatory, as acids would be rapidly neutralized by the calcareous spicules in the tunic or, in species lacking spicules, by neutralization in seawater. In contrast, several subsequent investigations have demonstrated an anti-predatory role for inorganic acids in ascidians. Pisut \& Pawlik (2002) demonstrated that acids at levels detected on the surfaces of ascidians were effective in deterring the generalist predatory fish Thalassoma bifasciatum. Moreover, McClintock et al. (2004) and the present study demonstrate that acids at levels found in outer tissues of some Antarctic ascidians can be effective deterrents against sea star predators. Contrary to Parry's (1984) claims that sulfuric acid is quickly neutralized in seawater, sulfuric acid-treated food pellets were not neutralized by seawater and retained their deterrent properties over the time course of sea star (McClintock et al. 2004) and fish feeding assays (Pisut \& Pawlik 2002, McClintock et al. 2004). More recently, Odate \& Pawlik (2007) proposed that the effects of low $\mathrm{pH}$ on the oxidation state of vanadium, a heavy metal common to ascidians, might increase the effectiveness of this metal as a feeding deterrent.

Over the past 2 decades it has become increasingly apparent that chemical defenses in Antarctic benthic macroalgae and sessile and sluggish marine invertebrates are not uncommon (reviewed in McClintock \& Baker 1997b, Amsler et al. 2001a,b, 2008, McClintock et al. 2005). Amsler et al. (2005) conducted an exhaustive survey of the palatability and chemical defenses of common Antarctic macroalgae and found a high incidence of chemical defenses against sea star, fish and amphipod predators. More recently, we conducted a similar survey of palatability and chemical defenses in common Antarctic peninsular sponges and found a high incidence of chemical defenses effective against both sea stars and fish predators (Peters et al. 2009). The present study demonstrates that chemical defenses against sea stars and fish that are attributable to secondary metabolites are not as prevalent in Antarctic solitary and colonial ascidians as they are in Antarctic macroalgae and sponges (Amsler et al. 2005, Peters et al. 2009). Nonetheless, inorganic chemical defenses (acids) are not uncommon in Antarctic ascidians and, while ineffective against fish, may deter sea star predation

Acknowledgements. We thank M. Amsler, C. Aumack and J. Zamzow for their assistance with field collections. We also thank M. Amsler and J. Zamzow for their assistance with running the fish bioassays. We are very grateful to L. Cole at the Smithsonian Institution, Washington, DC, for her assistance with ascidian taxonomy. We acknowledge the generous logistical support provided by those individuals employed by Raytheon Polar Services. This research was facilitated by NSF awards to C.D.A. and J.B.M. (OPP-0442769) and to B.J.B. (OPP-0442857). J.B.M. acknowledges the support of an Endowed Research Professorship in Polar and Marine Biology through the University of Alabama at Birmingham.

\section{LITERATURE CITED}

Amsler CD, Iken KB, McClintock JB, Baker BJ (2001a) Secondary metabolites from Antarctic marine organisms and their ecological implications. In: McClintock JB, Baker BJ (eds) Marine chemical ecology. CRC Press, Boca Raton, FL, p 267-300

Amsler CD, McClintock JB, Baker BJ (2001b) Secondary metabolites as mediators of trophic interactions among antarctic marine organisms. Am Zool 41:17-26

Amsler CD, Iken K, McClintock JB, Amsler MO and others (2005) Comprehensive evaluation of the palatability and chemical defenses of subtidal macroalgae from the Antarctic Peninsula. Mar Ecol Prog Ser 294:141-159

Amsler CD, McClintock JB, Baker BJ (2008) Macroalgal chemical defenses in polar marine communities. In: Amsler CD (ed) Algal chemical ecology. Springer-Verlag, Berlin, p 91-103

Amsler MO, McClintock JB, Amsler CD, Angus RA, Baker BJ (in press) Abundance and diversity of sponge-associated amphipods from the Antarctic Peninsula: are amphipods consuming sponges and do sponges possess amphipod anti-feedant compounds? Antarct Sci

Avila C, Taboada S, Núñez-Pons L (2008) Antarctic marine chemical ecology: What is next? PSZNI: Mar Ecol 29:1-71

Barrera-Oro E, Casaux R (1990) Feeding selectivity in Notothenia neglecta, Nybelin, from Potter Cove, South Shetland Islands, Antarctica. Antarct Sci 2:207-213

Barthel D, Wolfrath B (1989) Tissue sloughing in the sponge Halichondria panicea: a fouling organism prevents being fouled. Oecologia 78:357-360

Blankley W (1982) Feeding ecology of three inshore fish species at Marion Island (Southern Ocean). S Afr J Zool 17: 164-170

> Briscoe CS, Sebens KP (1988) Omnivory in Strongylocentrotus droebachiensis (Müller) (Echinodermata: Echinoidea): 
predation on subtidal mussels. J Exp Mar Biol Ecol 115: $1-24$

Burns E, Ilan M (2003) Comparison of anti-predatory defenses of Red Sea and Caribbean sponges. II. Physical defense. Mar Ecol Prog Ser 252:115-123

> Casaux RJ, Mazzotta AS, Barrera-Oro ER (1990) Seasonal aspects of the biology and diet of nearshore nototheniid fish at Potter Cove, South Shetland Islands, Antarctica. Polar Biol 11:63-72

> Chanas B, Pawlik JR (1995) Defenses of Caribbean sponges against predatory reef fish. II. Spicules, tissue toughness, and nutritional quality. Mar Ecol Prog Ser 127:195-211

Chanas B, Pawlik JR (1996) Does the skeleton of a sponge provide a defense against predatory reef fish? Oecologia 107:225-231

Cimino G, Ghiselin MT (2001) Marine natural products chemistry as an evolutionary narrative. In: McClintock JB, Baker BJ (eds) Marine chemical ecology. CRC Press, Boca Raton, FL, p 115-144

> Davis AR (1991) Alkaloids and ascidian chemical defense: evidence for the ecological role of natural products from Eudistoma olivaceum. Mar Biol 111:375-379

> Davis AR, Wright AE (1989) Interspecific differences in fouling of two congeneric ascidians (Eudistoma olivaceum and E. capsulatum): Is surface acidity an effective defense? Mar Biol 102:491-497

- Dayton PK, Robilliard GA, DeVries AL (1969) Anchor ice formation in McMurdo Sound, Antarctica, and its biological effects. Science 163:273-274

> Dayton PK, Robilliard GA, Paine RT, Dayton LB (1974) Biological accommodation in the benthic community at McMurdo Sound, Antarctica. Ecol Monogr 44:105-128

de Caralt S, Lopez-Legentil S, Tarjuelo I, Uriz MJ, Turon X (2002) Contrasting biological traits of Clavelina lepadiformis (Ascidiacea) populations from inside and outside harbours in the western Mediterranean. Mar Ecol Prog Ser 244:125-137

Faulkner DJ (2002) Marine natural products. Nat Prod Rep 19: $1-48$

Harvell C, Fenical W, Roussis V, Ruesink J, Griggs C, Greene $\mathrm{CH}$ (1993) Local and geographic variation in the defensive chemistry of a West Indian gorgonian coral (Briareum asbestinum). Mar Ecol Prog Ser 93:165-173

Hay ME, Kappel QE, Fenical W (1994) Synergisms in plant defenses against herbivores: interactions of chemistry, calcification, and plant quality. Ecology 75:1714-1726

Hirose E (1999) Pigmentation and acid storage in the tunic: protective functions of the tunic cells in the tropical ascidian Phallusia nigra. Invertebr Biol 118:414-422

Hirose E (2001) Acid containers and cellular networks in the ascidian tunic with special remarks on ascidian phylogeny. Zool Science 18:723-731

> Huang YM, McClintock JB, Amsler CD, Peters KJ, Baker BJ (2006) Feeding rates of common Antarctic gammarid amphipods on ecologically important sympatric macroalgae. J Exp Mar Biol Ecol 329:55-65

> Huang Y, Amsler MO, McClintock JB, Amsler CD, Baker BJ (2007) Patterns of gammaridean amphipod abundance and species composition associated with dominant subtidal macroalgae from the western Antarctic Peninsula. Polar Biol 30:1417-1430

- Iken K, Barrera-Oro E, Quartino M, Casaux R, Brey T (1997) Grazing by the Antarctic fish Notothenia coriiceps: evidence for selective feeding on macroalgae. Antarct Sci 9: 386-391

> Iken K, Quartino ML, Wiencke C (1999) Histological identification of macroalgae from stomach contents of the Ant- arctic fish Notothenia coriiceps using semi-thin sections. PSZN I: Mar Ecol 20:11-17

Kowalke J (1999) Filtration in Antarctic ascidians: striking a balance. J Exp Mar Biol Ecol 242:233-244

> Kowalke J, Tatián M, Sahade R, Arntz W (2001) Production and respiration of Antarctic ascidians. Polar Biol 24:663-669

Kühne S (1997) Solitäre Ascidien in der Potter Cove (King George Island, Antarktis): ihre ökologische Bedeutung und Populationsdynamik. Ber Polarforsch 252:1-153 (with English abstract)

> Lambert G, Lambert CC (1987) Spicule formation in the solitary ascidian, Herdmania momus. J Morphol 192:145-159

> Levine EP (1961) Occurrence of titanium, vanadium, chromium, and sulfuric acid in the ascidian Eudistoma ritteri. Science 133:1352-1353

Lindquist N, Fenical W (1991) New tambjamine class alkaloids from the marine ascidian Atapozoa sp. and its nudibranch predators. Origin of the tambjamines in Atapozoa. Cell Mol Life Sci V47:504-506

> Lindquist N, Hay ME, Fenical W (1992) Defense of ascidians and their conspicuous larvae: adult vs. larval chemical defenses. Ecol Monogr 62:547-568

> López-Legentil S, Turon X, Schupp P (2006) Chemical and physical defenses against predators in Cystodytes (Ascidiacea). J Exp Mar Biol Ecol 332:27-36

Mauzey KP, Birkeland C, Dayton PK (1968) Feeding behavior of asteroids and escape responses of their prey in the Puget Sound region. Ecology 49:603-619

> McClintock JB (1994) Trophic biology of antarctic shallowwater echinoderms. Mar Ecol Prog Ser 111:191-202

McClintock JB, Baker BJ (1997a) Palatability and chemical defense of eggs, embryos and larvae of shallow-water antarctic marine invertebrates. Mar Ecol Prog Ser 154: 121-131

McClintock JB, Baker BJ (1997b) A review of the chemical ecology of Antarctic marine invertebrates. Am Zool 37:329-342

> McClintock JB, Klinger TS, Lawrence JM (1984) Chemoreception in Luidia clathrata (Echinodermata: Asteroidea): qualitative and quantitative aspects of chemotactic responses to low molecular weight compounds. Mar Biol $84: 47-52$

McClintock JB, Pearse JS, Bosch I (1988) Population structure and energetics of the shallow-water antarctic sea star Odontaster validus in contrasting habitats. Mar Biol 99: 235-246

> McClintock JB, Heine J, Slattery M, Weston J (1991) Biochemical and energetic composition, population biology, and chemical defense of the antarctic ascidian Cnemidocarpa verrucosa Lesson. J Exp Mar Biol Ecol 147:163-175

McClintock JB, Baker BJ, Slattery M, Hamann M, Kopitzke R, Heine J (1994) Chemotactic tube-foot responses of a spongivorous sea star Perknaster fuscus to organic extracts from antarctic sponges. J Chem Ecol 20:859-870

> McClintock JB, Baker BJ, Amsler CD, Barlow TL (2000) Chemotactic tube-foot responses of the spongivorous sea star Perknaster fuscus to organic extracts of sponges from McMurdo Sound, Antarctica. Antarct Sci 12:41-46

McClintock JB, Amsler MO, Amsler CD, Southworth KJ, Petrie C, Baker BJ (2004) Biochemical composition, energy content and chemical antifeedant and antifoulant defenses of the colonial antarctic ascidian Distaplia cylindrica. Mar Biol 145:885-894

McClintock JB, Amsler CD, Baker BJ, van Soest RWM (2005) Ecology of Antarctic marine sponges: an overview. Integr Comp Biol 45:359-368

> Monteiro SM, Chapman MG, Underwood AJ (2002) Patches of the ascidian Pyura stolonifera (Heller, 1878): structure 
of habitat and associated intertidal assemblages. J Exp Mar Biol Ecol 270:171-189

Odate S, Pawlik JR (2007) The Role of vanadium in the chemical defense of the solitary tunicate, Phallusia nigra. J Chem Ecol 33:643-654

Parry DL (1984) Chemical properties of the test of ascidians in relation to predation. Mar Ecol Prog Ser 17:279-282

Paul VJ, Puglisi MP (2004) Chemical mediation of interactions among marine organisms. Nat Prod Rep 21:189-209

Paul VJ, Ritson-Williams R (2008) Marine chemical ecology. Nat Prod Rep 25:662-695

Paul VJ, Puglisi MP, Ritson-Williams R (2006) Marine chemical ecology. Nat Prod Rep 23:153-180

Pawlik JR (1993) Marine invertebrate chemical defenses. Chem Rev 93:1911-1922

> Peters KJ, Amsler CD, McClintock JB, van Soest RWM, Baker BJ (2009) Palatability and chemical defenses of sponges from the western Antarctic Peninsula. Mar Ecol Prog Ser 385:77-85

Petersen JK, Riisgård HU (1992) Filtration capacity of the ascidian Ciona intestinalis and its grazing impact in a shallow fjord. Mar Ecol Prog Ser 88:9-17

Peterson $\mathrm{CH}$, Renaud PE (1989) Analysis of feeding preference experiments. Oecologia 80:82-86

Pisut DP, Pawlik JR (2002) Anti-predatory chemical defenses of ascidians: secondary metabolites or inorganic acids? J Exp Mar Biol Ecol 270:203-214

Ramos-Espla AA, Carcel JA, Varela M (2005) Zoogeographical relationships of the littoral ascidiofauna around the Antarctic Peninsula, in the Scotia Arc and in the Magellan region. Sci Mar 69:215-223

Editorial responsibility: Paul Sammarco,

Chauvin, Louisiana, USA
Randall JE (1967) Food habits of reef fishes of the West Indies. Stud Trop Oceanogr 5:665-847

Sahade R, Tatián M, Kowalke J, Kühne S, Esnal GB (1998) Benthic faunal associations on soft substrates at Potter Cove, King George Island, Antarctica. Polar Biol 19:85-91

Sloan N (1980a) The arm curling and terminal tube-foot responses of the asteroid Crossaster papposus (L.). J Nat Hist 14:469-482

Sloan N (1980b) Aspects of the feeding biology of asteroids. Oceanogr Mar Biol Annu Rev 18:57-124

Sloan N, Campbell AC (1982) Perception of food. In: Jangoux M, Lawrence JM (eds) Echinoderm Nutrition. AA Balkema, Rotterdam, p 3-23

Sokal RR, Rohlf FJ (1994) Biometry, 3rd edn. WH Freeman, New York

Steinberg PD, Schneider R, Kjelleberg S (1997) Chemical defenses of seaweeds against microbial colonization. Biodegradation 8:211-220

Stoecker D (1978) Resistance of a tunicate to fouling. Biol Bull 155:615-626

Stoecker D (1980) Chemical defenses of ascidians against predators. Ecology 61:1327-1334

Tatian M, Sahade RJ, Doucet ME, Esnal GB (1998) Ascidians (Tunicata, Ascidiacea) of Potter Cove, South Shetland Islands, Antarctica. Antarct Sci 10:147-152

Webb DA (1939) Observations on the blood of certain ascidians, with special reference to the biochemistry of vanadium. J Exp Biol 16:499-523

Young CM, Bingham BL (1987) Chemical defense and aposematic coloration in larvae of the ascidian Ecteinascidia turbinata. Mar Biol V96:539-544

Submitted: April 14, 2009; Accepted: August 26, 2009

Proofs received from author(s): October 9, 2009 